\title{
Responses of California Annual Grassland Species to Variations in Moisture and Fertilization
}

\section{JAMES C. HULL AND CORNELIUS H. MULLER}

Highlight: The responses to fertilization and moisture of several of the principal grass species of the California annual type were measured in a field study in Southern California. Treatment plots were established in the grassland to examine the responses to a complete fertilizer. Comparisons were also made of grassland samples obtained in 2 years with different precipitation regimes. Fertilization increased the shoot weight of all species, but yield was increased for the brome species only. Oat species decreased in yield and numbers of shoots $/ \mathrm{m}^{2}$. In shoot weight the bromes had a similar but lesser response to additional moisture than to fertilization. With additional moisture the oat species increased in yield and numbers of shoots $/ \mathrm{m}^{2}$, but decreased in shoot weight. It is suggested that range management policies which increase nutrients or moisture might lead to an alteration of the composition of the annual grasslands.

The grasslands of California are referred to as the "annual type" (Talbot et al., 1939) due to the predominance of annual grass species. These grasslands are widely distributed in the coastal and central valleys of California where clay soils accumulate. Although composition of the annual type varies considerably, wild oat (Avena fatua), slender oat ( $A$. barbata), ripgut brome (Bromus rigidus), red brome (B. rubens), and soft chess (B. mollis) are among the primary gramineous contributions (Biswell, 1956).

The importance of soil fertility and soil moisture to this vegetation has been reported by many authors (Jenny et al., 1950; Love, 1952; McNaughton, 1968; Murphy, 1970; and Luebs et al., 1971). The problem to which this paper addresses is the responses of the principal grass species to fertilization as well as variations in soil moisture regime. The separate species are examined on the basis of changes in growth parameters

The authors are lecturer in biology and professor of botany, Department of Biological Sciences, University of California, Santa Barbara. The senior author is now with the Department of Biological Sciences, Bishop's University, Lennoxville, Quebec.

This work was supported by NSF grant GB 14891 to C. H. Muller. Manuscript received January 2, 1975. such as individual shoot weight, numbers of individuals per unit area, and species yield.

\section{Methods and Materials}

The grassland examined is in the Santa Ynez Valley of Santa Barbara County, Calif. The climate is characteristic of the California annual grasslands with cool, moist winters, and hot, dry summers. The average annual precipitation is $46 \mathrm{~cm}$ (18 inches). The soils are clay-loams derived from the Paso Robles Formation. The grassland was free from grazing by domestic animals during and prior to the period of study. Two grassland types were sampled equally in this study. The first was dominated by wild oat with contributions from ripgut brome and soft chess. The second area had a considerable complement of the perennial purple needlegrass (Stipa pulchra); however, an excess of $60 \%$ of the area was occupied by ripgut brome, soft chess, red brome, and slender oat (Hull, 1974). The contribution of forbs to the grasslands was minimal and, therefore, not included in the study.

\section{Fertilization}

The fertilization experiments were conducted in the 1972-1973 and the 1973-1974 growing seasons (hereafter referred to as the 1973 and 1974 growing seasons, respectively). Precipitation in the 1973 growing season totaled $74.2 \mathrm{~cm}$ (29.2 inches), and in the 1974 growing season totaled $42.8 \mathrm{~cm}$ ( 16.8 inches). In both years the precipitation which initiated widespread germination fell in the third week of November. Two plots, each $60 \times 100 \mathrm{~cm}$, constituted a treatment pair. To one plot a complete commercial fertilizer (Bandini "Gro-Rite" 6-10-4) was added by hand at the rate of $960 \mathrm{lb} / \mathrm{acre}$. This was equivalent to additions of $58,96,38$, and $67 \mathrm{lb} /$ acre of elemental nitrogen, phosphorus, potassium, and sulfur, respectively. The second plot, to which no fertilizer treatment was added, served as a control. The treatment pairs were replicated four times in each grassland for a total of eight treatments and corresponding controls. Each year the treatment pairs were in different locations.

The plots were sampled after the initiation of flowering in April. Sampling was performed with a ring having an area of $125 \mathrm{~cm}^{2}$. The ring was cast into the plot, and all the 
above-ground biomass of the species within the ring was collected. Each cast of the ring constituted a single sample. To collect only the annual grass species, care was taken to sample between the clones of the perennial grasses. Three samples were collected per plot in 1973, and five samples were collected per plot in 1974. This method yielded a total sample area of $0.3 \mathrm{~m}^{2}$ per treatment in 1973 and $0.5 \mathrm{~m}^{2}$ in 1974 . The samples were returned to the laboratory where each sample was separated into species which were counted for number of shoots, oven-dried, and weighed.

\section{Soil Moisture}

The importance of soil moisture to the growth of annual grass species was fortuitously measured during the 1972 and 1973 growing seasons. The 1972 growing season had a low total precipitation of $26.3 \mathrm{~cm}$ ( 10.3 inches), most of which fell in a single week in late December. Conversely, the 1973 growing season had an above-average total precipitation of $74.2 \mathrm{~cm}$, which was evenly distributed throughout the growing season. Germination was observed in early December of the 1972 growing season and in mid-November of the 1973 growing season. Soil moisture was monitored gravimetrically during both growing seasons at depths of $0^{-5}, 10^{-15}$, and $25-30 \mathrm{~cm}$. The soil moisture samples correspond to the depths of penetration of annual grass roots. The majority of these roots did not exceed $15 \mathrm{~cm}$ in depth. The permanent wilting point for the 10-15 cm depth was reached the second week of March 1972, and in the third week of April 1973. The 1972 growing season can be characterized as a short growing season of 4 months with germination occurring during a month of cool temperatures and with maturation coinciding with the unavailability of moisture in March. The 1973 growing season was nearly 6 months long with an earlier date of germination and a later date of soil moisture depletion.

The grass sampling technique utilized for the determination of yield in variable moisture years was in conjunction with another study (Hull, 1974). The sampling areas were approximately 1 acre each. The grassland predominated by annual grass species was sampled with the same $125 \mathrm{~cm}^{2}$ sampling ring previously described. A total of 80 samples was collected from this area in each growing season for a total of 1 $\mathrm{m}^{2}$. The second grassland containing purple needlegrass was divided into two equal areas to avoid disturbance caused by experimentation. One area was sampled in 1972 and the second in 1973 . Eighty $125-\mathrm{cm}^{2}$ samples were collected from between the clones of the purple needlegrass so as to collect only annual grass species. The combined sample area was 2.0 $\mathrm{m}^{2}$ for each year. Each sample was separated into species, which were counted for number of shoots, oven-dried, and weighed.

Differences in response to fertilization treatment or to moisture years were statistically analyzed using the $t$-test.

\section{Results}

The results of the fertilization experiments are presented in Table 1. Only those species with an excess of 100 shoots per $\mathrm{m}^{2}$ are included. For simplicity this table presents the combined data from the two grasslands for any one treatment. The pattern of results is not altered by this combination of data. For example, in only one instance did a response of a species in one grassland deviate from the combined results of both grasslands. In that case the yield of soft chess in 1974 declined with fertilization treatment in the annual grassland but increased in the grassland with purple needlegrass. Caution must be exercised in comparing proportions of the grass species to the total in the combined data to proportions in other grasslands. This is illustrated by the paucity of wild oat in the grassland with purple needlegrass and by the virtual absence of red brome in the annual grassland with wild oat (Hull, 1974).

The shoot weight as grams per individual increased significantly $(P<0.05)$ with fertilization for all species in both years (Table 1). The yield increased significantly for all species except wild and slender oat. The decline in yield of oats was significant for slender oat $(P<0.01)$. Red brome significantly increased in shoot number per unit area in both years. Ripgut brome increased in numbers in both years, but the increase was significant only in 1974. Soft chess decreased in numbers in both years with a significant reduction in 1973. Both oat species experienced a significant reduction in numbers with fertilization treatment. The proportion that a species contributed to the total yield was altered with fertilization for all species except soft chess. Red and ripgut brome increased, but wild and slender oat decreased in proportion to the total with fertilization treatment. Fertilization resulted in a significant increase in total yield in both years. The total

Table 1. Growth responses of annual grass species as shoot weight $(\mathrm{mg})$, yield $\left(\mathrm{g} / \mathrm{m}^{2}\right)$, number of shoots (no. $\left./ \mathrm{m}^{2}\right)$, and proportion of treatment yield $(\%)$ for control (C) and fertilized (F) treatments in two growing seasons (1973 and 1974).

\begin{tabular}{|c|c|c|c|c|c|c|c|c|c|c|c|c|}
\hline \multirow{3}{*}{$\begin{array}{c}\text { Year and } \\
\text { measurement }\end{array}$} & \multicolumn{12}{|c|}{ Plant species } \\
\hline & \multicolumn{2}{|c|}{ Soft chess } & \multicolumn{2}{|c|}{ Ripgut brome } & \multicolumn{2}{|c|}{ Red brome } & \multicolumn{2}{|c|}{ Wild oat } & \multicolumn{2}{|c|}{ Slender oat ${ }^{2}$} & \multicolumn{2}{|c|}{ Total } \\
\hline & $\mathrm{C}$ & $\mathrm{F}$ & $\mathrm{C}$ & $\mathrm{F}$ & $\mathrm{C}$ & $\mathrm{F}$ & $\mathrm{C}$ & $\mathrm{F}$ & $\mathrm{C}$ & $\mathrm{F}$ & $\mathrm{C}$ & $\mathrm{F}$ \\
\hline \multicolumn{13}{|l|}{1973} \\
\hline Shoot & & & & & & & & & & & & \\
\hline weight (mg) & 36 & $168 * 1$ & 111 & $296 * *$ & 50 & $240 * *$ & 184 & $314 * *$ & - & - & - & - \\
\hline Yield $\left(\mathrm{g} / \mathrm{m}^{2}\right)$ & 34.3 & $79.3 * *$ & 87.0 & $243.2 * *$ & 41.4 & $343.4 * *$ & 197.4 & 187.1 & - & - & 360.1 & $853.0^{*}$ \\
\hline $\begin{array}{l}\text { Number } \\
\text { (no. } / \mathrm{m}^{2} \text { ) } \\
\text { Proportion }\end{array}$ & 966 & $470 *$ & 780 & 820 & 817 & $1,427 * *$ & 1,073 & $594 *$ & - & - & 4,045 & 3,311 \\
\hline of yield $(\%)$ & 9.5 & 9.3 & 24.2 & 28.5 & 11.5 & 40.3 & 54.8 & 21.9 & - & - & 100.0 & 100.0 \\
\hline $\begin{array}{l}1974 \\
\text { Shoot }\end{array}$ & & & & & & & & & & & & \\
\hline weight (mg) & 14 & $30 * *$ & 37 & $133 * *$ & 14 & $60^{* *}$ & 107 & $154^{*}$ & 62 & $94 * *$ & - & - \\
\hline Yield $\left(\mathrm{g} / \mathrm{m}^{2}\right)$ & 73.0 & $105.9 *$ & 31.2 & $195.2 * *$ & 1.6 & $10.5^{*}$ & 171.4 & 139.2 & 33.1 & $18.1^{* *}$ & 310.3 & $468.9^{*}$ \\
\hline $\begin{array}{l}\text { Number } \\
\text { (no/m } \mathbf{m}^{2} \text { ) } \\
\text { Proportion }\end{array}$ & 5,146 & 3,530 & 841 & 1,467 & 108 & $172 * *$ & 1,596 & 901 & 534 & $196 * *$ & 8,225 & 6,266 \\
\hline of yield (\%) & 23.5 & 22.6 & 10.0 & 41.5 & 0.5 & 2.2 & 55.3 & 29.7 & 10.7 & 4.0 & 100.0 & 100.0 \\
\hline
\end{tabular}

Significant difference from control at $P<0.05\left(^{*}\right)$ or $P<0.01(* *)$ level of confidence.

${ }^{2}$ Slender oat was not present in 1973 treatment plots. 


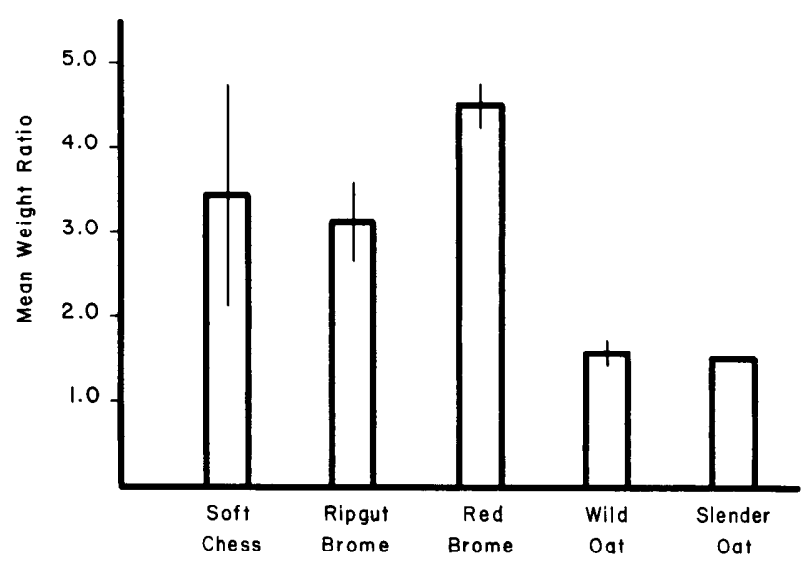

Fig. 1. The mean weight ratio (computed by dividing the individual shoot weight of the fertilized treatment by that of the control treatment) for each of the principal annual grass species. The histograms represent the averages, and the included bars represent the ranges of the ratios for the two sampling years. Slender oat was not sampled in 1973.

numbers of shoots declined in both years, but the differences were not significant.

Figure 1 presents the mean weight ratio for each grass species. This ratio is calculated by dividing the mean individual shoot dry weight of a species under fertilized treatment by that of the species under control treatment. (The ratio can be converted to percent of control by multiplying by 100.) An average ratio was computed for the 2 years and is represented by the histogram. The vertical bar within the histogram represents the range of the ratios between 1973 and 1974. Soft chess (3.43), ripgut brome (3.13), and red brome (4.50) had greater mean weight ratios than did wild oat (1.58) and slender oat (1.53).

The productivity ratio (Fig. 2) was computed by dividing the yield $\left(\mathrm{g} / \mathrm{m}^{2}\right)$ of a species under fertilization treatment by the productivity of the species without treatment. This ratio

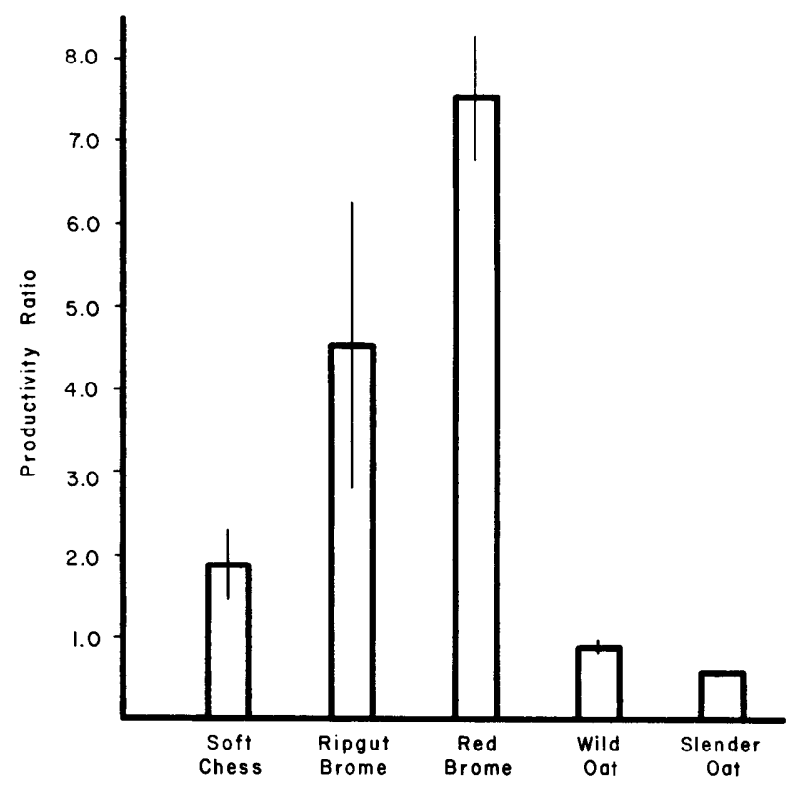

Fig. 2. The productivity ratio (computed by dividing the species yield under fertilization by that of the control treatment) for each of the principal annual grass species. The histograms represent the averages, and the included bars represent the ranges of the ratios for the two sampling years. Slender oat was not sampled in 1973. incorporates the important changes in the number of individuals and mean dry weight. As in the previous figure, the histograms represent the average of the ratios of the 2 years, and the vertical bars are the ranges of those ratios. Red brome had the highest productivity ratio (7.64), and was followed by ripgut brome (4.52), soft chess (1.86), wild oat (0.88), and slender oat $(0.56)$.

Table 2 presents the data from the 1972 and 1973 sampling of the grasslands for comparison of the effect of increased precipitation. As before, the data for the two grasslands are combined. The distributions of the brome species between the two sampling areas of the grassland with purple needlegrass were not uniform. In the first zone, sampled in 1972, soft chess predominated, and in the second zone, sampled in 1973, ripgut and red brome predominated. For this reason yield and shoot numbers for these species are not comparable between years and are omitted from the table. However, comparisons of shoot weight for all species and changes in yield and shoot numbers of wild oat are useful.

The shoot weight of ripgut and red brome was increased significantly $(P<0.05)$ in the wet year (Table 2$)$. Wild oat decreased significantly in shoot weight, but there was a significant increase in yield and numbers of individuals.

The mean weight ratios for the response of each species to moisture is presented in Figure 3. As before, this ratio is calculated by dividing the species mean dry weight in the wet year by that of the dry year. Red brome had the highest ratio (1.51), followed by soft chess (1.30), ripgut brome (1.30), and oat $(0.80)$.

\section{Discussion}

Analysis of the vegetative response to fertilization in the annual grassland indicated several important features. The three bromes had a greater response in mean dry weight to fertilization than did the oats. In numbers ripgut and red brome responded to fertilization with either no change, or an increase of individuals per square meter. Soft chess and the oats, conversely, decreased in numbers per square meter. The productivity of a species of grass is dependent upon the mean dry weight and the numbers of individuals per unit area. With fertilization the productivity of the brome grasses increased. Soft chess had a sufficient increase in mean dry weight to offset the reduction in numbers. Ripgut brome increased in mean dry weight to offset the reduction in numbers. Ripgut

Table 2. Growth responses of annual grass species as shoot weight $(\mathrm{mg})$, yield $\left(\mathrm{g} / \mathrm{m}^{2}\right)$, and number of shoots $\left(\mathrm{no} . / \mathrm{m}^{2}\right)$ for dry (1972) and wet (1973) growing seasons of $26.3 \mathrm{~cm}$ and $74.2 \mathrm{~cm}$ of precipitation.

\begin{tabular}{|c|c|c|c|c|}
\hline \multirow[b]{2}{*}{$\begin{array}{c}\text { Year and } \\
\text { measurement }\end{array}$} & \multicolumn{4}{|c|}{ Plant species } \\
\hline & $\begin{array}{l}\text { Soft } \\
\text { chess }\end{array}$ & $\begin{array}{l}\text { Ripgut } \\
\text { brome }\end{array}$ & $\begin{array}{c}\text { Red } \\
\text { brome }\end{array}$ & $\begin{array}{l}\text { Wild } \\
\text { oat }\end{array}$ \\
\hline \multicolumn{5}{|l|}{1972 (dry) } \\
\hline Shoot weight (mg) & 20 & 79 & 27 & 230 \\
\hline Yield $\left(\mathrm{g} / \mathrm{m}^{2}\right)^{1}$ & - & - & ... & 125.5 \\
\hline Number (no. $/ \mathrm{m}^{2}$ ) & - & - & - & 545 \\
\hline \multicolumn{5}{|l|}{1973 (wet) } \\
\hline Shoot weight (mg) & 26 & $103^{* 2}$ & $41 *$ & $184^{* *}$ \\
\hline Yield $\left(\mathrm{g} / \mathrm{m}^{2}\right)$ & - & - & - & $211.3 * *$ \\
\hline Number (no. $\left./ \mathrm{m}^{2}\right)$ & - & - & - & $1,151 * *$ \\
\hline
\end{tabular}

${ }^{1}$ Yield and number of shoots for the brome species are not comparable. See text.

${ }^{2}$ Significant differences in wet year at $P<0.05\left(^{*}\right)$ or $P<0.01\left(^{* *}\right)$ level of confidence. 


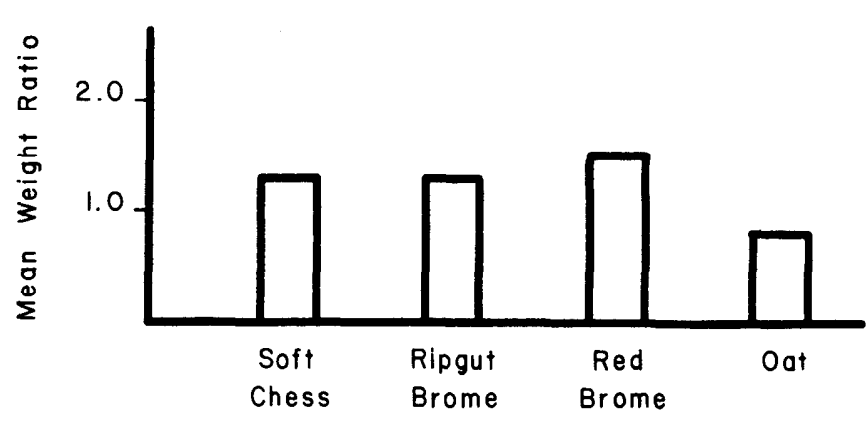

Fig. 3. The mean weight ratio (computed by dividing the individual mean weight in the wet year by that of the dry year) for each of the principal annual grass species expressed as a histogram.

brome increased in mean dry weight, and had an increase, or no change in numbers per unit area. This resulted in increased productivity with fertilization. Red brome increased in mean dry weight and in numbers, therefore it increased in productivity. The productivity of the oats, however, was reduced as a result of the substantial reduction in numbers per unit area. The proportion that a species contributed to the total was altered by fertilization for most species. With fertilization there was a shift in the importance of the brome species to the total. In 1973 the combined productivity of the bromes increased with fertilization from $45.2 \%$ to $79.1 \%$ of the total, and in 1974 the bromes increased from $34.1 \%$ to $66.4 \%$ of the total productivity.

The vegetative response to an increased moist ure supply was not as dramatic as that to fertilization. All species increased in mean dry weight except the oats. Comparison of the mean weight ratios of the fertilized treatments (Fig. 1) to the mean weight ratios for additional soil moisture (Fig. 3) indicates that although the response to fertilization is greater in magnitude for all species, there is a similar pattern of response between species to moisture and fertilization. Red brome had the greatest response followed by soft chess, ripgut brome, and the oats. Comparisons of the data found in Tables 1 and 2 for wild oat with regard to fertilization and moisture indicatc a difference in response. With fertilizer treatment, wild oat increased in shoot weight, decreased in shoot numbers, and had no significant change in yield. With additional moisture, wild oat decreased in shoot weight, increased in shoot number, and increased in yield.

With the addition of fertilizer or moisture an increase in productivity is cxpcctcd. This increased productivity could be manifested by increased survival of seedlings, increased mean weight, or both. A variation from the expected results suggests that interference, either in the form of competition or allelopathy, participates in causing the observed response. Such a variation is seen in the reduced yield of oats with fertilization. Competition implies that some physical factor is limiting the growth of the grass species, but the identity of this factor without experimentation can only be speculated upon. Allelopathy implies that one species is producing a toxic compound deleterious to the growth of a second species. The allelopathic reaction of wild oat has been demonstrated by Tinnin and Muller (1972); however, this potential for other annual grass species has not yet been documented.

Several important trends are expressed by these data. First, the relative importance of nutrient deficiencies as compared to soil moisture is documented. This was suggested previously by Love (1952). Second, the several grass species respond differentially to the addition of nutrients and moisture. For example, additional moisture has little effect on shoot weight of soft chess, but additional soil nutrients has a great effect. This suggests that each of the annual grasses has a different optimum and tolerance range with respect to soil nutrients and moisture. Third, the data suggest that wild and slender oat are near their growth optima, while the bromes are below their growth optima with respect to soil fertility and soil moisture. This is evidenced by the relative response of the brome species as compared with the oats to added fertilization and moisture as seen in the figures. A change in the grassland environment which results in the conservation of moisture and nutrients could result in an alteration of the proportionate composition of the grassland due to the differential requirements of the grass species. Fourth, with fertilization, productivity is increased with a concomitant increase in the interference capabilities of the species. Some species demonstrate a greater tolerance than do others to interference at higher levels of productivity. For example, with increased shoot productivity resulting from fertilization, ripgut and red brome had higher seedling survival than did soft chess and the oats.

Heady (1958) described changes in the proportion of species within the California annual type. He observed that without fire or grazing to remove mulch, ripgut brome and soft chess became major species in the annual grassland. Hervey (1949) demonstrated that fire alters the subsequent composition of grassland, and burning significantly decreases the productivity of soft chess, but not wild oats. Although their studies and the present one were performed in different portions of California, there is a striking correlation in the findings. The observation in this study that the brome species increased in productivity with fertilization correlates with the observations of the previous authors that mulch increases the brome species. This correlation assumes that mulch serves as a reservoir of available nutrients which are released by microbial activity, and that fire causes a reduction in the available nutrients due to losses from smoke and wind blown ash. Further investigation is needed on the role of nutrients in determining changes in composition of the grasslands of the California annual type.

\section{Literature Cited}

Biswell, H. H. 1956. Ecology of California grasslands. J. Range Manage. 9:19-24.

Heady, H. F. 1958. Vegetational changes in the California annual type. Ecology 39:402-416.

Hervey, D. F. 1949. Reaction of a California annual-plant community to fire. J. Range Manage. 2:116-121.

Hull, J. C. 1974. The potential for dominance by Stipa pulchra in a California grassland. $\mathrm{PhD}$ Diss. University of California, Santa Barbara. $100 \mathrm{p}$.

Jenny, H., J. Vlamis, and W. E. Martin. 1950. Greenhouse assay of fertility of California soils. Hilgardia 20:1-18.

Love, R. M. 1952. Range improvement experiments on the Arthur E. Brown ranch, California. J. Range Manage. 5:120-123.

Luebs, R. E., A. E. Lang, and M. B. Brown. 1971. Effect of site class and rainfall on annual range response to nitrogen and phosphorus. J. Range Manage. 24:366-370.

McNaughton, S. J. 1968. Structure and function in California grasslands. Ecology 49:962-972.

Murphy, A. H. 1970. Predicted forage yield based on fall precipitation in California annual grasslands. J. Range Manage. 23:363-365.

Talbot, M. W., H. H. Biswell, and A. L. Hormay. 1939. Fluctuations in the annual vegetation of California. Ecology 20:394-402.

Tinnin, R. O., and C. H. Muller. 1972. The allelopathic influence of Avena fatua: The allelopathic mechanism. Bull. Torrey Bot. Club 99:287-292. 